\title{
Different Diets Cause Alterations in the Enteric Environment and Trigger Changes in the Expression of Hepatic Cytochrome P450 3A, a Drug-Metabolizing Enzyme
}

\author{
Masataka Tajima, ${ }^{a, b, \#}$ Nobutomo Ikarashi, ${ }^{a, \#}$ Shintaro Igeta, ${ }^{a}$ Takahiro Toda, ${ }^{a}$ \\ Makoto Ishii, ${ }^{a}$ Yoshikazu Tanaka,${ }^{c}$ Yoshiaki Machida, ${ }^{c}$ Wataru Ochiai, ${ }^{a}$ Harumi Yamada,${ }^{b}$ and \\ Kiyoshi Sugiyama*,a \\ ${ }^{a}$ Department of Clinical Pharmacokinetics, Hoshi University; ${ }^{c}$ Division of Applied Pharmaceutical Education and \\ Research, Hoshi University; 2-4-41 Ebara, Shinagawa-ku, Tokyo 142-8501, Japan: and ${ }^{b}$ Department of \\ Pharmaceutical Sciences, International University of Health and Welfare; 2600-1 Kitakanemaru, Ohtawara, Tochigi \\ 324-8501, Japan. \\ Received November 19, 2012; accepted January 21, 2013; advance publication released online February 1, 2013
}

\begin{abstract}
Changes in the expression level and activity of cytochrome P450 (CYP) in the liver are caused by various factors and affect the pharmacokinetics of drugs. The purpose of this study was to determine whether the expression of CYP3A is affected by a high-fat diet. In addition, we examined whether the type of diet given to mice could produce changes in the expression level and activity of CYP3A. Mice were fed a purified diet containing $10 \mathrm{kcal} \%$ lard (control group) or $60 \mathrm{kcal} \%$ lard (HF group) or regular mouse chow containing $13 \mathrm{kcal} \%$ of fat (MF group) for 4 weeks. No significant differences were observed in the hepatic CYP3A protein expression level between the HF group and the control group. The CYP3A protein expression in the MF group was significantly higher than that observed in the control group. In the MF group, the area under the curve $(A U C)$ of intraperitoneally administered triazolam was lower. Because lithocholic acid (LCA) is known to increase hepatic CYP3A expression, the levels of Clostridium sordellii and LCA in the feces were measured. In the MF group, the levels of Clostridium sordellii and LCA were higher. It has been demonstrated that a high-fat diet does not cause any changes in hepatic CYP3A expression. In addition, the different diets caused alterations in the enteric environment, which triggered changes in CYP3A expression. Therefore, it is necessary to carefully consider the type of feed while performing animal experiments to evaluate the pharmacokinetics of drugs.
\end{abstract}

Key words cytochrome P450; high-fat diet; lithocholic acid; liver

Cytochrome P450 (CYP) is a drug-metabolizing enzyme that is mainly expressed in the liver. There are various subtypes of CYP, and CYP3A is one of the most important subfamilies because approximately $50 \%$ of the drugs used in clinical practice today are metabolized by CYP3A. ${ }^{1)}$ The expression level and activity of CYP3A are affected by not only exogenous substances ${ }^{2,3)}$ but also endogenous substances, such as bile acid $^{4-6)}$ and hormones. ${ }^{7,8)}$ In addition, it has been demonstrated that the expression level and activity of CYP3A are affected by diseases including diabetes mellitus. ${ }^{9,10)} \mathrm{Re}$ cently, it has been reported that the expression levels of CYPs are also altered in response to the intake of fatty acids ${ }^{11,12)}$ and vitamins. ${ }^{13,14)}$ It is obvious that the expression and activity of CYPs are affected by various factors. Understanding the factors that affect CYPs expression and activity are very important for the proper use of drugs, since changes in the expression level and activity of CYPs affect the pharmacokinetics of drug substrate.

Over the past few years, the intake of a high-fat diet has increased as a result of the Westernization of diets. The excessive intake of a high-fat diet increases the risk for diabetes, hyperlipidemia, and hypertension, and therefore, a high-fat diet has become a problem worldwide. ${ }^{15)}$ It has been reported that a high-fat diet can cause changes in the expression levels of various enzymes in the liver. ${ }^{16,17)}$ However, only a few studies have investigated how a high-fat diet affects the expression

The authors declare no conflict of interest.

\# These authors contributed equally to this work. level and activity of CYP3A in the liver, and consensus has not been reached. ${ }^{18-20)}$ The purpose of this study is to examine how the expression level of CYP3A in the liver is affected by a high-fat diet. In this study, the effect of a high-fat diet on the expression level of hepatic CYP3A in mice was examined by using a feed prepared from purified components, whose nutritional content and origin were known. In addition, we examined the effect of different types and amounts of nutrients in the feed on the expression level and activity of CYP3A using regular mouse chow.

\section{MATERIALS AND METHODS}

Materials Triazolam was purchased from Wako Pure Chemical Industries, Ltd. (Osaka, Japan). Bovine serum albumin (BSA), TRI reagent, ethylenediaminetetraacetic acid (EDTA), and $\alpha$-hydroxytriazolam were purchased from Sigma-Aldrich Corp. (St. Louis, MO, U.S.A.). The 4-hydroxytriazolam was purchased from BIOMOL (Exeter, U.K.). The nicotinamide adenine dinucleotide phosphate (NADPH) regenerating system was purchased from Becton, Dickinson and Company (Tokyo, Japan). Rabbit anti-rat CYP3A2 antibody was purchased from Daiichi Pure Chemicals (Tokyo, Japan). Donkey anti-rabbit immunoglobulin G-horseradish peroxidase (IgG-HRP) antibody and an enhanced chemiluminescence system (ECL) plus Western blotting detection reagents were purchased from GE Healthcare (Chalfont, St. Giles, U.K.). A QIAamp DNA stool mini kit was purchased from Qiagen Inc. (Valencia, CA, U.S.A.). A high capacity cDNA synthesis kit 
Table 1. The Components of Each Diet

\begin{tabular}{|c|c|c|c|c|c|c|}
\hline & \multicolumn{2}{|c|}{ D12450B (Control) } & \multicolumn{2}{|c|}{ D12492 (High-fat) } & \multicolumn{2}{|c|}{ MF (Regular chow) } \\
\hline & $\mathrm{g}$ & kcal $\%$ & g & $\mathrm{kcal} \%$ & $\mathrm{~g}$ & $\mathrm{kcal} \%$ \\
\hline Fat & 4.3 & 10 & 34.9 & 60 & 5.3 & 13 \\
\hline Protein & 19.2 & 20 & 26.2 & 20 & 23.6 & 26 \\
\hline Carbohydrates & 67.3 & 70 & 26.3 & 20 & 54.4 & 61 \\
\hline Other & 9.2 & 0 & 12.5 & 0 & 16.7 & 0 \\
\hline Total & 100 & 100 & 100 & 100 & 100 & 100 \\
\hline $\mathrm{kcal} / \mathrm{g}$ & \multicolumn{2}{|c|}{3.85} & \multicolumn{2}{|c|}{5.24} & \multicolumn{2}{|c|}{3.6} \\
\hline
\end{tabular}

Table 2. The Ingredients of Each Diet

\begin{tabular}{|c|c|c|c|c|c|c|}
\hline & \multicolumn{3}{|c|}{ D12450B } & \multicolumn{3}{|c|}{ D12492 } \\
\hline & $\mathrm{g}$ & kcal & $\mathrm{kcal} \%$ & $\mathrm{~g}$ & kcal & $\mathrm{kcal} \%$ \\
\hline Casein, 80 Mesh & 19.0 & 76 & 19.7 & 25.8 & 103 & 19.7 \\
\hline L-Cystine & 0.3 & 1 & 0.3 & 0.4 & 2 & 0.3 \\
\hline Corn starch & 29.9 & 119 & 31 & 0 & 0 & 0 \\
\hline Maltodextrin 10 & 3.3 & 13 & 3 & 16.2 & 65 & 12.3 \\
\hline Sucrose & 33.2 & 133 & 35 & 8.9 & 36 & 6.8 \\
\hline Cellulose, BW200 & 4.7 & 0 & 0 & 6.5 & 0 & 0 \\
\hline Soybean oil & 2.4 & 21 & 5.5 & 3.2 & 29 & 5.5 \\
\hline Lard & 1.9 & 17 & 4.4 & 31.7 & 285 & 54.3 \\
\hline Mineral Mix S10026 & 0.95 & 0 & 0 & 1.3 & 0 & 0 \\
\hline Dicalcium phosphate & 1.23 & 0 & 0 & 1.7 & 0 & 0 \\
\hline Calcium carbonate & 0.52 & 0 & 0 & 0.7 & 0 & 0 \\
\hline Potassium citrate, $\mathrm{H}_{2} \mathrm{O}$ & 1.56 & 0 & 0 & 2.1 & 0 & 0 \\
\hline Vitamin Mix V10001 & 0.95 & 3.8 & 1.0 & 1.3 & 5.2 & 1.0 \\
\hline Choline bitartrate & 0.19 & 0 & 0 & 0.3 & 0 & 0 \\
\hline FD\&C Red dye & 0.005 & 0 & 0 & & & \\
\hline FD\&C Yellow dye & & & & 0.006 & 0 & 0 \\
\hline Total & 100 & 385 & 100 & 100 & 524 & 100 \\
\hline
\end{tabular}

was purchased from Applied Biosystems (Foster City, CA, U.S.A.), and iQ SYBR green supermix was purchased from Bio-Rad Laboratories (Hercules, CA, U.S.A.). Primers were purchased from Invitrogen Corp. (Tokyo, Japan). All the other reagents were of the highest grade that was commercially available.

Animals Male ICR mice (9 weeks old) were purchased from Japan SLC, Inc. (Shizuoka, Japan). The mice were divided into 3 groups after being on a purified diet containing $10 \mathrm{kcal} \%$ of lard as fat (D12450B, Research Diets, New Brunswick, NJ, U.S.A.) for 1 week. Each group was allowed access to either purified feed with $10 \mathrm{kcal} \%$ of lard (D12450B; control group), purified feed with $60 \mathrm{kcal} \%$ of lard (D12492, Research Diets; HF group), or regular mouse chow (MF, Oriental Yeast, Tokyo, Japan; MF group), ad libitum, for 1 week or 4 weeks (Tables 1-3). Regular mouse chow contains corn, fish meal, defatted rice bran, nonfat dry milk, and brewer's yeast.

After administration, their body weight was measured, and blood samples were collected from the abdominal part of the vena cava under ether anesthesia. The liver, small intestine, and white adipose tissue (around the testes, retroperitoneum, and kidney) were removed and weighed. The liver and small intestine were flash frozen in liquid nitrogen and stored at
Table 3. The Contents of Vitamin of Each Diet

\begin{tabular}{lcc}
\hline \hline & D12450B & MF \\
\hline Vitamin A (IU) & 379 & 2160 \\
Vitamin $\mathrm{D}_{3}(\mathrm{IU})$ & 95 & 158 \\
Vitamin E (mg) & 4.7 & 11 \\
Vitamin B (mg) & 0.6 & 2.1 \\
Nicotinic acid (mg) & 2.8 & - \\
Vitamin B $(\mu \mathrm{g})$ & 0.9 & 5.3 \\
Vitamin C (mg) & - & 4.0 \\
Inositol (mg) & - & 578 \\
\hline
\end{tabular}

$-80^{\circ} \mathrm{C}$.

The mice were housed at room temperature $\left(24 \pm 1^{\circ} \mathrm{C}\right)$ and $55 \pm 5 \%$ humidity with $12 \mathrm{~h}$ of light (artificial illumination: 08:00-20:00). The present study was conducted in accordance with the Guiding Principles for the Care and Use of Laboratory Animals, as adapted by the Committee on Animal Research at Hoshi University.

Blood Analysis The blood samples were centrifuged $\left(1000 \times \boldsymbol{g}\right.$ for $15 \mathrm{~min}$ at $\left.4^{\circ} \mathrm{C}\right)$, and the plasma was stored at $-80^{\circ} \mathrm{C}$ until assay. The concentrations of glucose, triglyceride, total cholesterol, and free fatty acids in the plasma were 
quantified enzymatically using a Glucose CII Test (Wako Pure Chemical Ind., Ltd.), Triglyceride E-Test Wako (Wako Pure Chemical), Cholesterol E-Test Wako (Wako Pure Chemical, and NEFA C-Test Wako (Wako Pure Chemical), respectively.

Extraction of RNA from Tissue Samples RNA was extracted from approximately $15 \mathrm{mg}$ of frozen liver tissue using TRI reagent. The resulting solution was diluted 50 -fold using Tris/EDTA buffer (TE buffer), and the purity and concentration $(\mu \mathrm{g} / \mathrm{mL})$ of RNA were calculated by measuring the absorbance at 260 and $280 \mathrm{~nm}$ using a U-2800 spectrophotometer (Hitachi High Technologies, Tokyo, Japan).

Real-Time Polymerase Chain Reaction (PCR) A highcapacity cDNA synthesis kit was used to synthesize the cDNA from $1 \mu \mathrm{g}$ of RNA. cDNA TE buffer solution was prepared by diluting cDNA 20 -fold using TE buffer. The expression of target genes was detected by preparing the primers and by performing real-time PCR. The following were added to each well of the 96-well PCR plate: $25 \mu \mathrm{L}$ of iQ SYBR green supermix, $3 \mu \mathrm{L}$ of forward primer of the target gene $(5 \mathrm{pmol} /$ $\mu \mathrm{L}), 3 \mu \mathrm{L}$ of reverse primer $(5 \mathrm{pmol} / \mu \mathrm{L}), 4 \mu \mathrm{L}$ of $\mathrm{cDNA}$ TE buffer solution, and $15 \mu \mathrm{L}$ of RNase-free water. For $18 \mathrm{~S}$ ribosomal RNA (rRNA), a housekeeping gene, $2 \mu \mathrm{L}$ of a cDNA TE buffer solution was used, which was prepared by diluting the abovementioned solution 20-fold using TE buffer. Regarding the PCR conditions, the denaturation temperature was set at $95^{\circ} \mathrm{C}$ for $15 \mathrm{~s}$, annealing temperature was set at $56^{\circ} \mathrm{C}$ for $30 \mathrm{~s}$, and elongation temperature was set at $72^{\circ} \mathrm{C}$ for $30 \mathrm{~s}$. The fluorescence intensity of the amplification process was monitored using the My $\mathrm{iQ}^{\mathrm{TM}}$ single-color real-time reverse transcription (RT)-PCR detection system (Bio-Rad Laboratories). The following pairs of primers were used: for CYP3A11, the forward primer was $5^{\prime}$-cgectctcettgctgtcaca- $3^{\prime}$ and the reverse primer was $5^{\prime}$-ctttgcettctgcctcaagt-3', and for $18 \mathrm{~S}$ rRNA, the forward primer was $5^{\prime}$-gtctgtgatgccettagatg- $3^{\prime}$ and the reverse primer was 5'-agcttatgacccgcacttac-3'. The mRNA level of CYP3A11 was normalized to the level of $18 \mathrm{~S}$ rRNA.

Microsome Preparation Approximately $100 \mathrm{mg}$ of liver or small intestinal mucosa scraped with a slide glass was homogenized in the dissection buffer $(0.3 \mathrm{M}$ sucrose; $25 \mathrm{~mm}$ imidazole; $1 \mathrm{~mm}$ EDTA; $8.5 \mu \mathrm{M}$ leupeptin; and $1 \mu \mathrm{M}$ phenylmethylsulfonyl fluoride, $\mathrm{pH}$ 7.2). The resulting suspension was centrifuged $\left(9000 \times \boldsymbol{g}\right.$ for $15 \mathrm{~min}$ at $\left.4^{\circ} \mathrm{C}\right)$, and the supernatant was centrifuged $\left(105000 \times \boldsymbol{g}\right.$ for $1 \mathrm{~h}$ at $\left.4^{\circ} \mathrm{C}\right)$. Dissection buffer was added to the precipitate, which was then homogenized using an ultrasonic homogenizer (UH-50, SMT Co., Ltd., Tokyo, Japan) to yield the microsomal fraction. ${ }^{5,9)}$

Electrophoresis and Immunoblotting Protein concentrations were measured by using the Lowry method, ${ }^{21)}$ with BSA as the standard. Electrophoresis was performed using Laemmli's method. ${ }^{22)}$ Proteins were diluted 2-fold using loading buffer ( $84 \mathrm{~mm}$ Tris; 20\% glycerol; 0.004\% bromophenol blue; $4.6 \%$ sodium dodecyl sulfate (SDS); and 10\% 2-mercaptoethanol, $\mathrm{pH}$ 6.8), and the samples were boiled for $5 \mathrm{~min}$ prior to loading on a polyacrylamide gel. After electrophoresis was completed, the isolated proteins were transferred to a polyvinylidene difluoride (PVDF) membrane, which was incubated in $1 \%$ skim milk blocking buffer for $1 \mathrm{~h}$. After blocking, the membrane was incubated with rabbit anti-rat CYP3A2 antibody $(1: 15000)$ for $1 \mathrm{~h}$ at room temperature. After washing the membrane with TBS-Tween (20 mM Tris- $\mathrm{HCl} ; 137 \mathrm{~mm} \mathrm{NaCl}$; and $0.1 \%$ Tween $20, \mathrm{pH} 7.6$ ), the membrane was incubated with donkey anti-rabbit IgG-HRP antibody $(1: 10000)$ for $1 \mathrm{~h}$ at room temperature. Then, the membrane was incubated with the ECL plus detection reagent, and the bands visualized with a LAS-3000 Mini Lumino image analyzer (FUJIFILM, Tokyo, Japan).

Measurement of CYP3A Metabolic Activity Fifty microliters of triazolam solution (final concentrations ranged from $0-750 \mu \mathrm{M}), 44 \mu \mathrm{L}$ of hepatic microsomal suspension (final concentration was $0.27 \mathrm{mg} / \mathrm{mL}$ ), and $6 \mu \mathrm{L}$ of $\mathrm{NADPH}$ regenerating system solution were placed in a microtube and incubated for $30 \mathrm{~min}$ at $37^{\circ} \mathrm{C}$. The reaction was stopped by the addition of $200 \mu \mathrm{L}$ of acetonitrile and was cooled by placing it on ice. The sample was centrifuged $(16000 \times \boldsymbol{g}$ for $15 \mathrm{~min}$ at $4{ }^{\circ} \mathrm{C}$ ), and the supernatant was evaporated under a flow of nitrogen. The residue was dissolved in the HPLC mobile phase [acetonitrile:methanol:10 mM potassium phosphate buffer ( $3: 6: 11, \mathrm{pH} 7.4)]$, and HPLC-UV was used to quantify 4-hydroxytriazolam and $\alpha$-hydroxytriazolam. ${ }^{10,23)}$ The initial linear rate conditions have been confirmed with respect to microsomal protein concentration (up to $1 \mathrm{mg} / \mathrm{mL}$ ) and incubation time (up to $40 \mathrm{~min}$ ).

The relationship between the triazolam concentration and metabolic rate was fitted to the Michaelis-Menten equation (4-hydroxylation) or the Michaelis-Menten equation with substrate inhibition ( $\alpha$-hydroxylation) using the nonlinear least-squares regression program (MULTI) to calculate the kinetic parameters (maximum velocity: $V_{\max }$, Michaelis constant: $K_{\mathrm{m}}$, and substrate inhibition constant: $K_{\mathrm{s}}$ ). Furthermore, we calculated the intrinsic clearance $\left(C L_{\text {int }}=V_{\max } / K_{\mathrm{m}}\right)$ for each metabolic pathway. ${ }^{24)}$

Triazolam Pharmacokinetics In the control and MF groups, $0.3 \mathrm{mg} / \mathrm{kg}$ triazolam (polyethylene glycol: saline $=1: 9$ solution) was administered intraperitoneally. At 15, 30, 60, and $120 \mathrm{~min}$ after drug administration, blood samples were collected from the abdominal vena cava using a heparinized syringe (five individuals/time point). The blood samples were centrifuged to isolate the plasma.

After adding $300 \mu \mathrm{L}$ of isopropanol to $300 \mu \mathrm{L}$ of plasma, the sample was mixed, centrifuged $(15000 \times \boldsymbol{g}$ for $10 \mathrm{~min}$ at $25^{\circ} \mathrm{C}$ ), and deproteinated. Next, $450 \mu \mathrm{L}$ of borate buffer $(50 \mathrm{~mm}$; pH 11) and $1620 \mu \mathrm{L}$ of chloroform were added to $360 \mu \mathrm{L}$ of the supernatant, and the sample was subsequently mixed and centrifuged $\left(1000 \times \boldsymbol{g}\right.$ for $5 \mathrm{~min}$ at $\left.25^{\circ} \mathrm{C}\right)$. The lower layer was collected and dried with nitrogen gas. The residue was dissolved in $30 \mu \mathrm{L}$ of mobile phase, and triazolam was assayed by HPLC-UV. ${ }^{25)}$

Data Analysis The area under the plasma concentrationtime curve extrapolated to infinity $\left(A U C_{\text {infinity }}\right)$ was calculated using the average concentration obtained from five mice for each time point with the linear trapezoidal rule. The elimination rate constant $\left(k_{\mathrm{el}}\right)$ and elimination half-life $\left(t_{1 / 2}=0.693 / k_{\mathrm{el}}\right)$ were calculated from the concentration profiles of the elimination phase. The maximum plasma concentration $\left(C_{\max }\right)$ and time-to-maximum plasma concentration $\left(t_{\max }\right)$ were obtained from actual measurements. Body clearance $(C L / F$, where $F$ is bioavailability) was calculated using the following formula:

$$
C L / F(\mathrm{~mL} / \mathrm{min})=\operatorname{dose}(\mu \mathrm{g}) / A U C_{\text {infinity }}(\mu \mathrm{g} \cdot \mathrm{min} / \mathrm{mL})
$$

$F$ is treated as a constant because the same formulation of triazolam was used, and we assumed that the bioavailability did not change between different mice. ${ }^{26}$ 
A

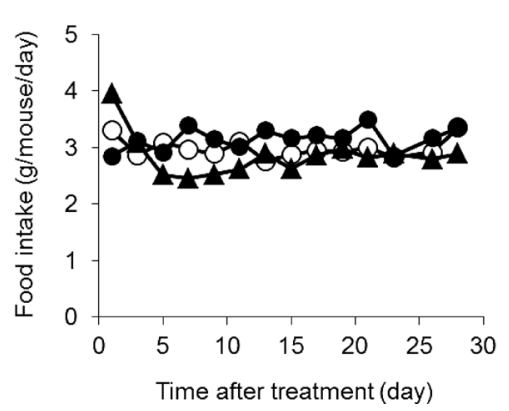

B

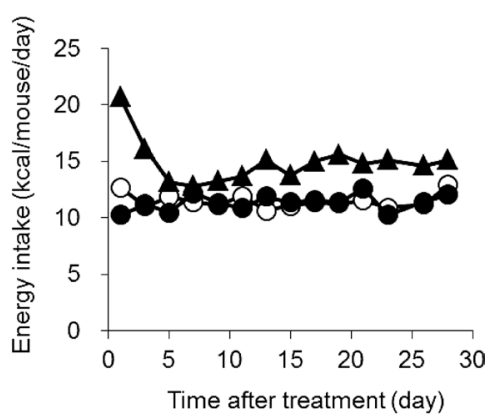

Fig. 1. Feed (A) and Caloric Intake (B)

The mice were allowed free access to the control diet (O), high-fat diet ( $\mathbf{\Delta})$, or regular mouse chow (MF; $\bullet$ ) for 4 weeks. The amount of feed intake was measured (A), and caloric intake was calculated (B).

HPLC-UV The HPLC apparatus consisted of a Waters 2695 Separation Module (Waters, Tokyo, Japan) and a Waters $2489 \mathrm{UV} /$ Visible Detector (Waters), and the measured data were recorded and analyzed using Empower analysis software (Waters). We used an Inertsil C18 ODS-3 column (mean particle size: $5 \mu \mathrm{m}, 4.6 \times 250 \mathrm{~mm}$, GL Sciences Inc., Tokyo, Japan), and the mobile phase was acetonitrile-methanol-10 mm potassium phosphate buffer $(3: 6: 11, \mathrm{pH} 7.4)$. The flow rate was $1.0 \mathrm{~mL} / \mathrm{min}$, the temperature was $40^{\circ} \mathrm{C}$, and the detection wavelength was $220 \mathrm{~nm}$. The retention times for $\alpha$-hydroxytriazolam, 4-hydroxytriazolam, and triazolam were $13 \mathrm{~min}, 15 \mathrm{~min}$, and $17 \mathrm{~min}$, respectively.

Quantification of Lithocholic Acid-Producing Bacteria DNA was extracted from approximately $200 \mathrm{mg}$ of frozen feces using the QIAamp DNA stool mini kit, which was performed according to the manufacturer's protocol. The resulting solution was diluted 50 -fold using TE buffer, its purity was confirmed, and the DNA concentration $(\mu \mathrm{g} / \mathrm{mL})$ was calculated by measuring absorbance at 260 and $280 \mathrm{~nm}$ using a spectrophotometer.

The expression of intestinal flora was detected by synthesizing primers and performing real-time PCR. The following were added to each well of the 96-well PCR plate: $25 \mu \mathrm{L}$ of iQ SYBR green supermix, $3 \mu \mathrm{L}$ of forward primer of the target gene $(5 \mathrm{pmol} / \mu \mathrm{L}), 3 \mu \mathrm{L}$ of reverse primer $(5 \mathrm{pmol} / \mu \mathrm{L}), 4 \mu \mathrm{L}$ of cDNA TE buffer solution, and $15 \mu \mathrm{L}$ of RNase-free water. Regarding the PCR conditions, the denaturation temperature was set at $95^{\circ} \mathrm{C}$ for $30 \mathrm{~s}$, annealing temperature was set at $60^{\circ} \mathrm{C}$ for $30 \mathrm{~s}$, and elongation temperature was set at $72^{\circ} \mathrm{C}$ for $1 \mathrm{~min}$. The following pairs of primers were used: for Clostridium sordellii, the forward primer was $5^{\prime}$-tcgagcgaccttcgg-3' and the reverse primer was $5^{\prime}$-caccacctgtcaccat-3'.

Quantification of Lithocholic Acid in the Feces A total of $15 \mathrm{~mL}$ of ethyl acetate was added to approximately $30 \mathrm{mg}$ of a freeze-dried feces sample, and the mixture was sonicated to form a suspension. A total of $150 \mu \mathrm{L}$ of $\mathrm{HCl}$ solution was added to the suspension to obtain a non-ionic form of lithocholic acid (LCA), which was extracted into the ethyl acetate phase. The mixture was agitated for $2 \mathrm{~h}$ in a warm bath at $50^{\circ} \mathrm{C}$. The suspension was centrifuged $(12000 \times \boldsymbol{g}$ for $10 \mathrm{~min}$ at $4^{\circ} \mathrm{C}$ ), and the supernatant was dried under nitrogen gas. The residue was dissolved in $1 \mathrm{~mL}$ of acetonitrile and mixed with $25 \mu \mathrm{L}$ of 6,7-dimethoxy-1-methylquinoxalin-2(1H)-one solution, $25 \mu \mathrm{L}$ of 18 -crown- 6 solution, and $5 \mathrm{mg}$ of $\mathrm{K}_{2} \mathrm{CO}_{3}$. The mixture was heated for $20 \mathrm{~min}$ at $80^{\circ} \mathrm{C}$ in the dark. After cooling, the mixture was centrifuged $(13400 \times \mathbf{g}$ for $1 \mathrm{~min}$ at $25^{\circ} \mathrm{C}$ ). The supernatant was used as a sample for HPLCfluorescence $(\mathrm{FL}){ }^{27)}$

HPLC-FL The HPLC apparatus consisted of a Waters 2695 Separation Module and a Waters $2475 \lambda$ Fluorescence Detector (Waters), and the measured data were recorded and analyzed using Empower analysis software. We used an Inertsil C18 ODS-3 column, and the mobile phase was wateracetonitrile-methanol $(21: 66: 13)$. The flow rate was set at $2.0 \mathrm{~mL} / \mathrm{min}$, and the temperature was $40^{\circ} \mathrm{C}$. The excitation and detection wavelengths were $370 \mathrm{~nm}$ and $455 \mathrm{~nm}$, respectively. $^{28,29)}$

Statistical Analysis Numerical data are expressed as the means \pm standard deviation. The significance of the differences between the means was examined using Student's $t$-test for pairs of values and Dunnett's test for multiple comparisons. Results with $p<0.05$ were considered to be statistically significant.

\section{RESULTS}

Feed Intake and Caloric Intake Using purified feed that contained $10 \mathrm{kcal} \%$ of lard as the control, a high-fat diet containing $60 \mathrm{kcal} \%$ of lard was prepared and given to mice for a period of 4 weeks. In addition, regular mouse chow containing $13 \mathrm{kcal} \%$ of various types of fat, whose nutritional composition was different from those present in the purified feed, was given to the mice for 4 weeks.

Figure 1 depicts the changes in the feed and caloric intake of the mice over time.

The feed intake of the control group, HF group, and MF group was approximately $3 \mathrm{~g} / \mathrm{mouse} / \mathrm{d}$ and did not differ significantly between the different groups throughout the administration period (Fig. 1A).

The caloric intake of the HF group was approximately $15 \mathrm{kcal} / \mathrm{mouse} / \mathrm{d}$ and was maintained at a higher level compared to that of the control group (approximately $11 \mathrm{kcal} /$ mouse/d) throughout the administration period. However, the caloric intake between the control group and the MF group was not significantly different (Fig. 1B).

The Effect of a High-Fat Diet on Body Weight and the Weight of the Liver and White Adipose Tissue Body weight and the weight of the liver and the white adipose tissue of the mice that received either the control diet, high-fat diet, or MF diet for 4 weeks were measured (Fig. 2). 
A

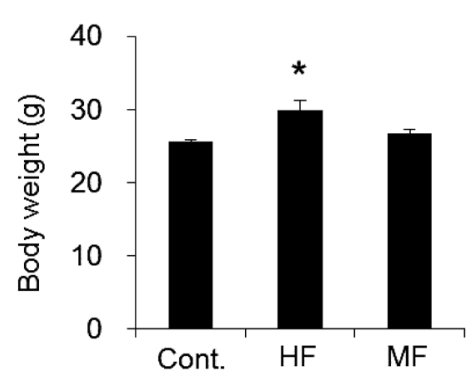

B

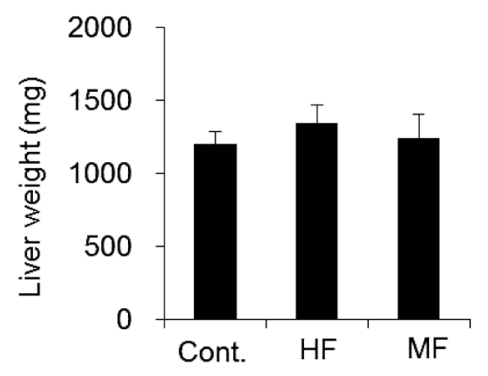

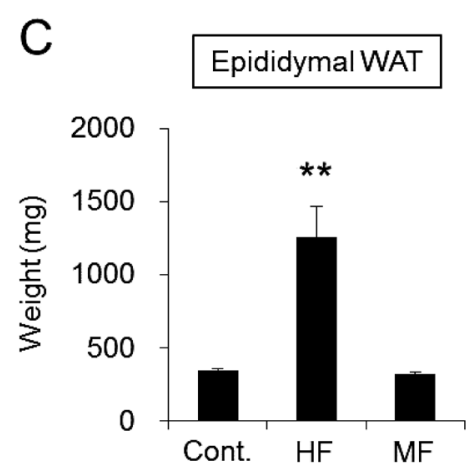
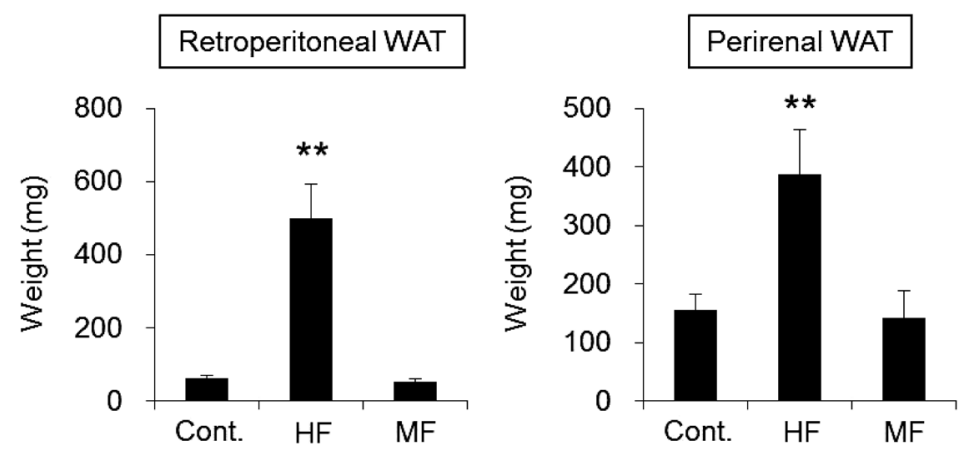

Fig. 2. Measurement of Body Weight, Liver Weight, and the Weight of White Adipose Tissue

The mice were allowed free access to the control diet, high-fat diet, or regular mouse chow (MF) for 4 weeks. The body weight (A), and the weight of the liver (B) and the weight white adipose tissue (WAT) around the testes, kidney, and mesentery (C) were measured. Data are presented as the means \pm S.D. and were obtained from five mice per group. Dunnett's test was performed to test to determine the statistical significance between the groups. ${ }^{*} p<0.05$ and ${ }^{* *} p<0.01$ vs. the control group were determined to be statistically significant.

A

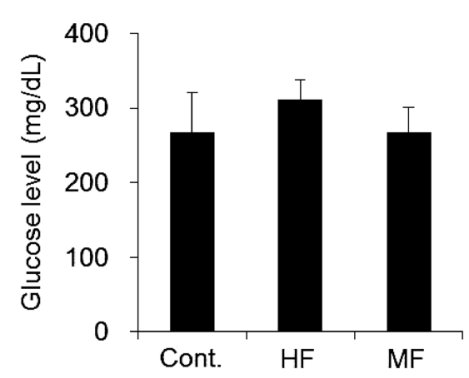

$\mathrm{C}$

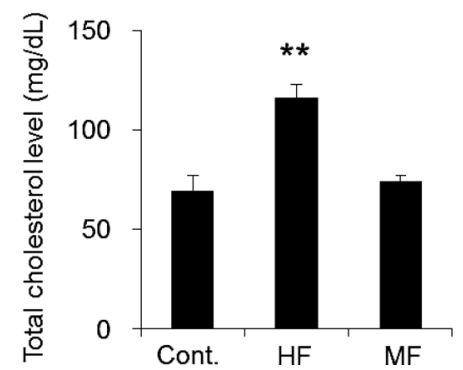

B

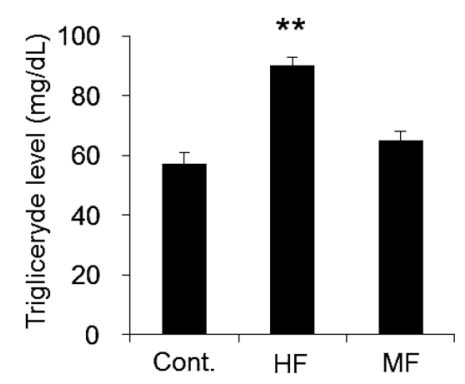

D

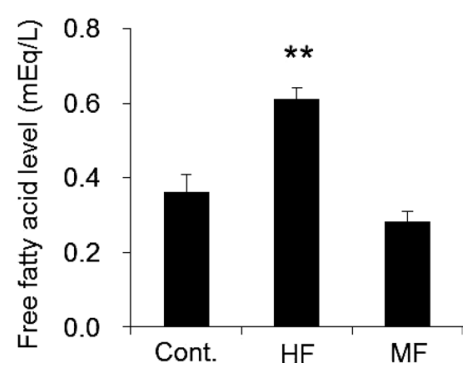

Fig. 3. Biochemical Profile of the Murine Plasma

The mice were allowed free access to the control diet, high-fat diet, or the regular mouse chow (MF) for 4 weeks. Blood samples were collected to measure glucose (A), triglyceride (B), total cholesterol (C), and free fatty acid (D) levels. Data are presented as the means \pm S.D. and were obtained from five mice per group. Dunnett's test was performed to test to determine the statistical significance between the groups. ${ }^{*} p<0.01 v s$. the control group were determined to be statistically significant.

The body weight and the weight of the white adipose tissue in the mice that belonged to the HF group were significantly greater than that observed in mice from the control group, demonstrating signs of mild obesity (Figs. 2A, C). In contrast, significant differences were not observed in the liver weight between the control group and the HF group (Fig. 2B). 

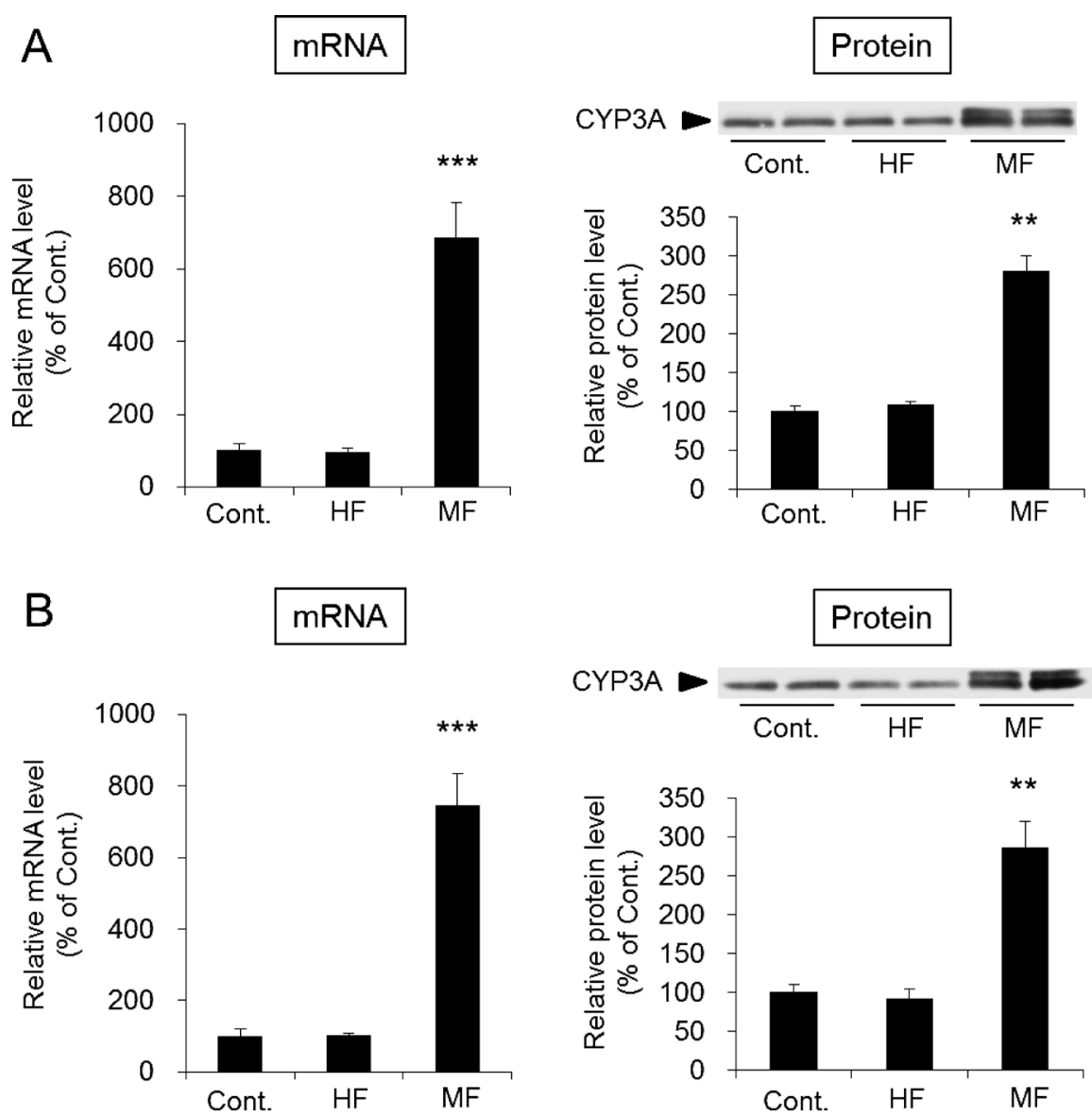

Fig. 4. The Expression Level of CYP3A11 mRNA and CYP3A Protein in the Liver

The mice were allowed free access to the control diet, high-fat diet, or regular mouse chow (MF) for 1 week (A) or 4 weeks (B). CYP3A11 mRNA expression levels in the liver were measured by performing real-time RT-PCR and were normalized to $18 \mathrm{~S}$ rRNA. Microsomal fractions were prepared from the liver, and the expression levels of CYP3A protein were measured by performing western blotting analysis. The results have been presented by setting the mean of the control group as $100 \%$. Data are presented as the means \pm S.D. and were obtained from five mice per group. Dunnett's test was performed to test to determine the statistical significance between the groups. $* * p<0.01$ and $* * * p<0.001 v s$. the control group were determined to be statistically significant.

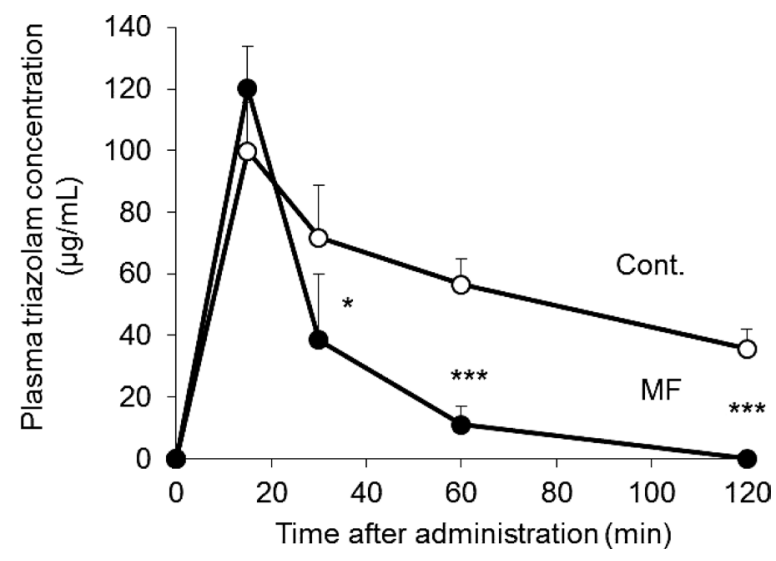

Fig. 5. Triazolam Pharmacokinetics

The mice were allowed free access to either the control diet $(\bigcirc)$ or regular mouse chow $(\mathrm{MF}, 0)$ for 4 weeks. Triazolam was administered intraperitoneally $(0.3 \mathrm{mg}$ / $\mathrm{kg}$ ) to the mice, and the plasma concentrations of triazolam were measured by performing the HPLC-UV analysis until 120 min after the drug administration. Student's $t$-test was performed to test to determine the statistical significance between the groups. Data are presented as the means \pm S.D. and were obtained five mice per group. $* p<0.05$ and $* * * p<0.001 v s$. the control group were determined to be statistically significant.

No significant differences were observed in the body weight, liver weight, and weight of the white adipose tissue between the MF group and the control group (Fig. 2).
Table 4. Triazolam Pharmacokinetic Parameters

\begin{tabular}{llcc}
\hline \hline & & Control & MF \\
\hline$A U C_{0-\infty}$ & $(\mu \mathrm{g} \cdot \mathrm{min} / \mathrm{mL})$ & 10.7 & 3.2 \\
$C L / F$ & $(\mathrm{~mL} / \mathrm{min})$ & 1.1 & 3.8 \\
$C_{\max }$ & $(\mathrm{ng} / \mathrm{mL})$ & $100 \pm 16$ & $120 \pm 12$ \\
$T_{\max }$ & $(\mathrm{min})$ & 15 & 15 \\
$k_{\mathrm{el}}$ & $\left(\mathrm{min}^{-1}\right)$ & 0.009 & 0.054 \\
$T_{1 / 2}$ & $(\mathrm{~min}$ & 77 & 13 \\
\hline
\end{tabular}

The mice were allowed free access to either the control diet or regular mouse chow (MF) for 4 weeks. Triazolam was administered intraperitoneally to the mice in the control group and the MF group, and the plasma concentrations of triazolam were measured by performing HPLC-UV analysis until $120 \mathrm{~min}$ after the drug administration. The pharmacokinetic parameters were calculated my measuring the changes in the plasma concentrations of triazolam after administration (Fig. 5) by using the methods described in Materials and Methods. $C_{\max }$ is presented as the means \pm S.D. and is obtained five mice per group.

The Effect of the High-Fat Diet on the Biochemical Profiles of Blood The levels of non-fasting blood glucose, plasma triglycerides, total cholesterol, and free fatty acids were measured in mice that were fed either the control diet, high-fat diet, or MF diet for 4 weeks (Fig. 3).

No significant differences were observed in the non-fasting blood glucose level between the HF group and the control group. However, the levels of plasma triglyceride, total cholesterol, and free fatty acids were significantly higher in the HF 

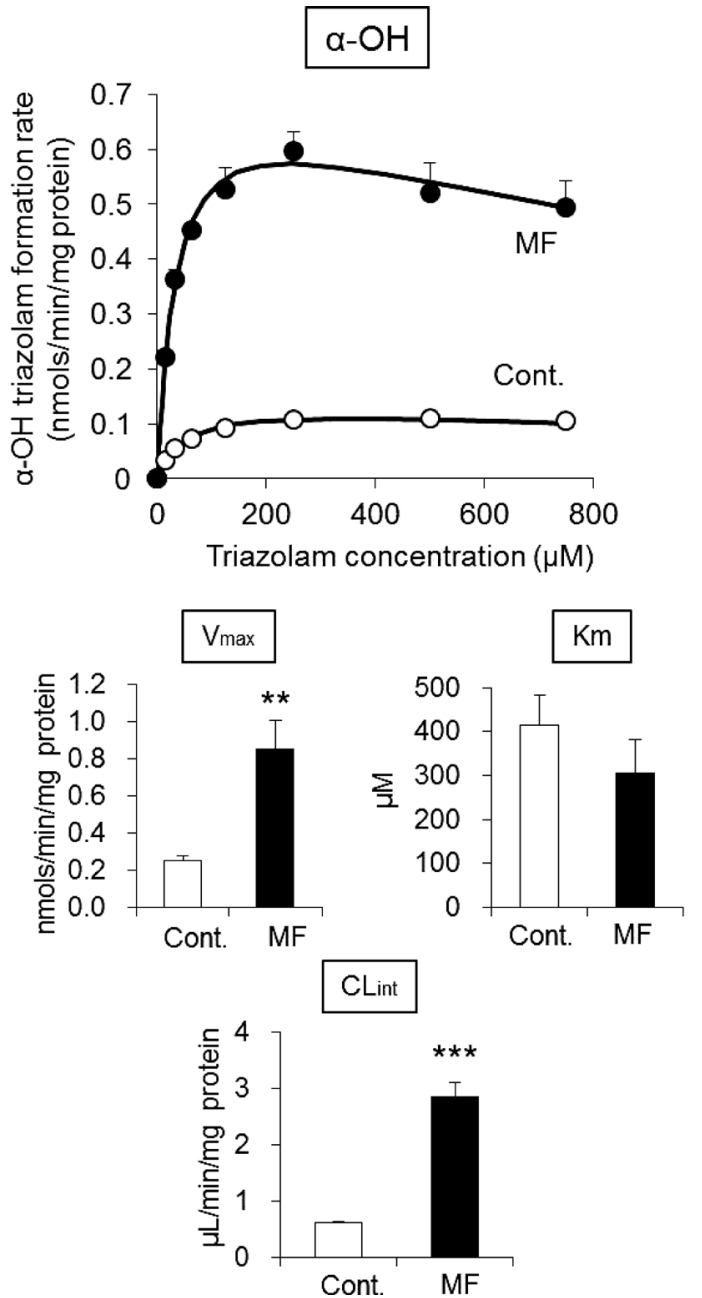
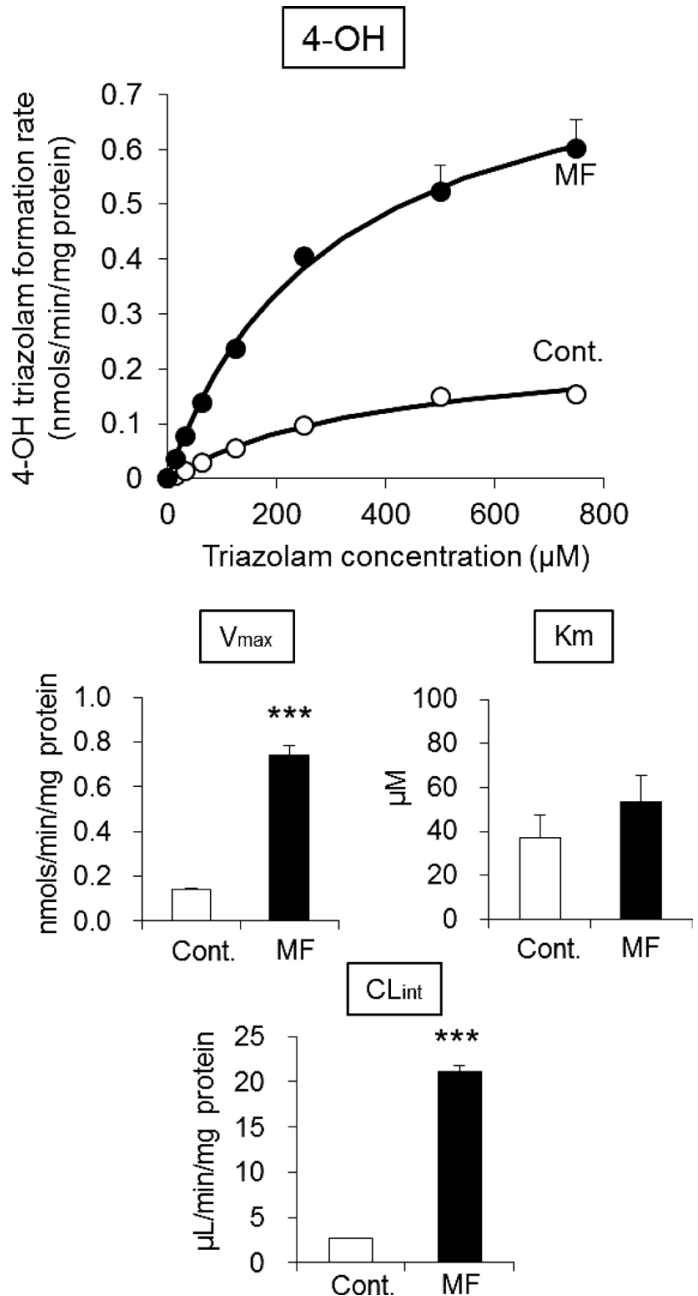

Fig. 6. Triazolam Metabolic Activity in the Hepatic Microsomal Fraction

The mice were allowed free access to either the control diet or regular mouse chow (MF) for 4 weeks. Microsomal fractions were prepared from the liver, and the activities of the 4-hydroxy (4-OH) and $\alpha$-hydroxy $(\alpha-\mathrm{OH})$ metabolites of triazolam were determined. The kinetic parameters for each metabolite were also calculated. Data are presented as the means \pm S.D. and were obtained from five mice per group. Student's $t$-test was performed to determine the statistical significance between the groups. $* * p<0.01$ and $* * * p<0.001 v s$. the control group were determined to be statistically significant.

group than in the control group.

The levels of plasma triglyceride, total cholesterol, and free fatty acids were not significantly different between the MF group and the control group.

The Expression Levels of CYP3A11 mRNA and CYP3A Protein in the Liver The levels of CYP3A11 mRNA and CYP3A protein expression were analyzed in the liver of mice that received either the control diet, high-fat diet, or MF diet for 1 week or 4 weeks (Fig. 4).

Compared to the control group, no significant differences were observed in the levels of CYP3A11 mRNA expression in the liver of mice that were on a HF diet for 1 week or for 4 weeks. Further, changes in the level of CYP3A protein expression due to the intake of a HF diet were not observed.

However, the level of CYP3A11 mRNA expression in the liver of mice that were fed the MF diet for 1 week was significantly higher (approximately 7 times) than that observed in the control group. The level of CYP3A protein expression in the MF group also showed a significant increase compared to the control group. Similarly, the expression levels of CYP3A11 mRNA and CYP3A protein were also significantly higher in mice on the MF diet for 4 weeks compared with the control group (increased by approximately 7 times and 3 times, respectively).

Triazolam Pharmacokinetics We examined whether the MF diet-induced increase in the expression level of CYP3A protein could cause changes in the pharmacokinetics of a CYP3A drug substrate (Fig. 5). In this study, triazolam was used as the drug substrate for CYP3A. It is known that triazolam is metabolized by CYP3A in humans and by its ortholog in mice to produce $\alpha$-hydroxytriazolam and 4-hydroxytriazolam. ${ }^{23)}$ Many of the CYP3A substrates also act as substrates for P-glycoprotein (P-gp), a transporter that mediates drug excretion. ${ }^{30,31)}$ However, triazolam is not a $\mathrm{P}-g \mathrm{p}$ substrate. ${ }^{32)}$ Therefore, triazolam was intraperitoneally administered to mice that were fed either the control diet or MF diet for 4 weeks, and the plasma concentration of triazolam was measured to calculate its pharmacokinetic parameters (Fig. 5, Table 4).

In both these groups, the $C_{\max }$ of triazolam was achieved at $15 \mathrm{~min}$ after drug administration, which was followed by a gradual decline in the plasma concentration of triazolam. The plasma concentration of triazolam in the MF group at 30,60, and $120 \mathrm{~min}$ after drug administration was significantly lower than that observed in the control group (Fig. 5). In the MF group, the $A U C_{\text {infinity }}$ of triazolam decreased to approximately 
$30 \%$ of the value that was observed in the control group, whereas the $C L / F$ increased by approximately 3.5 -fold compared to the control group (Table 4).

Triazolam Metabolic Activity in the Hepatic Microsomal Fraction We examined whether the increase in triazolam clearance observed after the intake of the MF diet could be attributed to an increase in the intrinsic hepatic clearance of the drug (Fig. 6). The hepatic microsomal fractions were prepared from mice that were fed either the control diet or the MF diet for 4 weeks. The amounts of $\alpha$-hydroxytriazolam and 4-hydroxytriazolam produced by the metabolism of triazolam in this hepatic microsomal fraction were measured to evaluate the metabolic activity of CYP3A.

The $V_{\max }$ of $\alpha$-hydroxylation in the MF group was significantly higher than that observed in the control group. $C L_{\text {int }}$ in the MF group was significantly higher (approximately 4 times) than that observed in the control group. However, the $K_{\mathrm{m}}$ values did not differ significantly were between the control group and the MF group. Regarding $\alpha$-hydroxylase activity, the decrease in the rate of metabolism was associated with an increase in the triazolam concentration. This could be attributed to substrate inhibition that is caused by the formation of the enzyme-substrate complex, which is formed by the binding of CYP3A to triazolam, its substrate. ${ }^{33)}$

The $V_{\max }$ and $C L_{\text {int }}$ of the 4-hydroxylation activity were significantly higher (approximately 5 times) in the MF group than in the control group. However, no significant differences were observed in the $K_{\mathrm{m}}$ value between the control group and the MF group.

The Levels of Clostridium sordellii and LCA in the Feces The expression level of CYP3A in the liver is increased by LCA, which is produced by enteric bacteria, Clostridium sordellii. ${ }^{4-6)}$ Therefore, we examined whether the changes in the enteric environment that were caused by dietary modifications might be responsible for LCA-induced increase in CYP3A expression level. In this study, the levels of Clostridium sordellii (LCA-producing bacteria) and LCA in the feces of mice that were fed the control diet or MF diet for 4 weeks were measured (Fig. 7).

The level of Clostridium sordellii in the feces of mice from the MF group was significantly higher (approximately 3 times) than that observed in mice from the control group (Fig. 7A). Similarly, the LCA content in the feces of mice from the MF group was significantly higher (approximately 2.5 times) than that observed in mice from the control group (Fig. 7B).

CYP3A Protein Expression Level in the Small Intestine The expression level of CYP3A protein was analyzed in the small intestine of mice that received the control diet or $\mathrm{MF}$ diet for 4 weeks (Fig. 8).

The level of CYP3A protein expression in the small intestine of mice that were fed the MF diet was significantly higher (approximately 2.3 times) than that observed in the control group (Fig. 8).

\section{DISCUSSION}

In recent years, the intake of foods with high-fat content has increased as a result of the Westernization of the diet. When medications are taken with a high-fat meal, the pharmacokinetics of the drug can be altered. For example, when highly lipophilic medications, such as phenytoin ${ }^{34)}$ and cyclosporine, ${ }^{35)}$

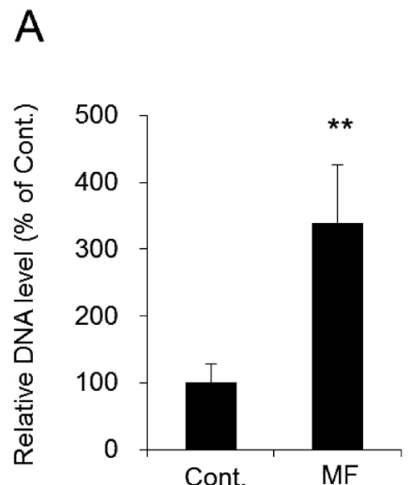

B

Fig. 7. The Levels of Clostridium sordellii (A) and LCA (B) in the Feces

The mice were allowed free access to either the control diet or regular mouse chow (MF) for 4 weeks. (A) The amount of Clostridium sordellii DNA in the feces of mice was measured by using real-time PCR. (B) LCA was extracted from the feces, and its concentration was measured by using HPLC. Data are presented as the means \pm S.D. and were obtained five mice per group. Student's $t$-test was performed to determine the statistical significance between the groups. $* * p<0.01 v s$. the control group was determined to be statistically significant.
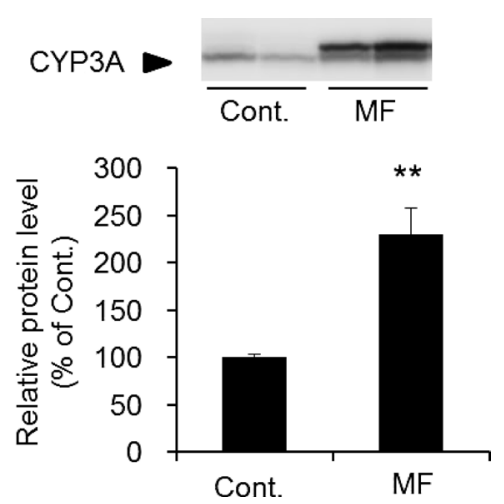

Fig. 8. The Expression Level of CYP3A Protein in the Small Intestine

The mice were allowed free access to the control diet or regular mouse chow (MF) for 4 weeks. Microsomal fractions were prepared from the small intestine, and the expression levels of CYP3A protein were measured by performing western blotting analysis. The results have been presented by setting the mean of the control group as $100 \%$. Data are presented as the means \pm S.D. and were obtained from five mice per group. Student's $t$-test was performed to determine the statistical significance between the groups. $* * p<0.01$ vs. the control group was determined to be statistically significant.

are taken with high-fat meals, the absorption of these drugs is increased, which results in an increase in their $A U C$. However, it is not clear whether the expression level of CYP3A, which is a drug-metabolizing enzyme, would be altered by the continuous intake of a high-fat diet. Therefore, in this study, we examined whether the expression of hepatic CYP3A is affected by the intake of a high-fat diet.

The expression levels of CYP3A11 mRNA and CYP3A proteins were analyzed in the liver of mice that were fed a high-fat diet, prepared from purified feed, for 4 weeks. Our results did not show any significant differences between the control group and the HF group (Fig. 4). It was therefore concluded that the expression level of hepatic CYP3A is not affected by energy intake in the form of fat or carbohydrate (Table 1). Our results also suggest that a continuous increase in caloric intake does not alter the expression level of the hepatic CYP3A protein (Fig. 1). These results are different from those previously reported, in which the daily intake of a high-fat diet markedly decreased the expression level of 
hepatic CYP3A in mice. ${ }^{20)}$ This discrepancy may be explained by a difference in the type of feed given to the mice. In previous studies, the change in CYP3A levels was compared between mice fed a high-fat diet prepared from purified feed and those fed a control diet composed of crude feed (MF; Oriental Yeast Co., Ltd.). ${ }^{20)}$ The expression level and activity of hepatic CYP3A are known to be affected by the type of feed given to animals. ${ }^{36,37)}$ We investigated the extent to which the expression level and activity of hepatic CYP3A in mice were altered by the consumption of different feeds. More specifically, regular mouse chow, which contained corn and fish meal (Oriental Yeast), was compared with the control diet, which consisted of purified feed (control group). The results revealed that the expression level of CYP3A protein in the liver of mice that were on the regular mouse chow was significantly higher (approximately 3 times) than that observed in mice from the control group, even though the caloric intake was the same between the two groups (Figs. 1, 4). This finding is consistent with the results of a similar study that compared the effect of a standard diet (AM-II; Hope Farms, the Netherlands) to that of a semisynthetic diet (20\% casein, 4068.02; Hope Farms). ${ }^{38)}$ The present study suggests that the decrease in the expression level of hepatic CYP3A that was previously attributed to the intake of a high-fat diet may instead result from differences in the composition of the feeds used, independent of their fat content. ${ }^{20)}$

We also examined whether the changes in CYP3A expression level were due to the differences in the feed, which could affect the pharmacokinetics of drugs such as triazolam, a CYP3A substrate. A decrease in the $A U C$ and an increase in the $C L / F$ of triazolam were observed in the MF group compared to the control group (Fig. 5, Table 4). The results of the CYP3A metabolic activity using the hepatic microsomal fraction suggest that these changes in the $A U C$ and $C L / F$ could be attributed to an increase in the intrinsic hepatic clearance of triazolam (Fig. 6). Based on these results, it was concluded that the intake of the regular mouse chow increases the metabolic activity of hepatic CYP3A in mice, which causes a decrease in the plasma concentration of a drug that is the CYP3A substrate

We investigated the cause of the increase in CYP3A expression level in the murine liver after the intake of regular mouse chow. The results of the pathological examination showed that there were no signs of obesity, diabetes, or hyperlipidemia in the MF group (Figs. 2, 3). The caloric intake in the MF group was comparable to that observed in the control group (Fig. 1). Similar to the control group, the main energy source in the MF group was carbohydrates (Table 1). Therefore, the possibility that the increase in CYP3A expression level in the liver of mice in the MF group was due to pathological conditions, caloric intake, or energy source was considered to be low.

The CYP3A expression level in the liver is affected by the presence of exogenous and endogenous substances. For example, LCA, a secondary bile acid that is produced by enteric bacteria, activates hepatic nuclear receptors such as pregnane $\mathrm{X}$ receptor (PXR), ${ }^{39,40)}$ farnesoid $\mathrm{X}$ receptor $(\mathrm{FXR}),{ }^{41,42)}$ and vitamin D receptor (VDR). ${ }^{43,44)}$ Activation of these receptors stimulates the transcription of CYP3A11, resulting in an increase in the expression levels of CYP3A proteins. The mechanism that mediates the increase in the CYP3A expression in the liver caused by the regular mouse chow was therefore examined, focusing on LCA. The production of LCA involves the metabolism of chenodeoxycholic acid, a reaction that is catalyzed by $7 \alpha$-dehydroxylase, which is derived from the enteric bacteria that are similar to those that belong to the genus Clostridium. ${ }^{45)}$ In this study, the level of Clostridium sordellii, which possesses high $7 \alpha$-dehydroxylase activity, was quantitatively analyzed by performing real-time PCR. The results showed that the level of Clostridium sordelli in the feces of the mice in the MF group was significantly higher than that observed in mice in the control group (Fig. 7A). The LCA content in the feces of mice in the MF group was also significantly higher than that observed for mice in the control group (Fig. 7B). Neither the control diet nor the MF diet contained LCA (data not shown). These results suggest that the increased expression levels of hepatic CYP3A proteins in the MF group may be partially attributed to an increase in LCA levels resulting from a change in intestinal flora induced by components of the regular mouse chow. ${ }^{46-48)}$ It is also possible that the composition of the regular mouse chow could increase the levels of chenodeoxycholic acid, the precursor of LCA. This effect would increase LCA levels and could subsequently lead to an increase in CYP3A. ${ }^{49,50)}$

In an in vitro study using rat and human small intestinal cells and hepatic parenchymal cells, Khan et al. have reported that LCA induces CYP3A strongly in the small intestine but weakly in the liver. ${ }^{51)}$ In our study, in contrast, the expression level of CYP3A in the small intestine of the MF group was increased relative to the control group, and this increase was comparable to that in the liver (Figs. 4, 8). The reasons for the discrepancy between the results reported by Khan et al. and our results may include differences in the animal species used (humans and rats in the study of Khan et al. and mice in our study) and in the experimental system employed (in vitro in the study of Khan et al. and in vivo in our study). ${ }^{51)}$

Regular mouse chow contains various ingredients, and the specific ingredients contribute to the observed increase in LCA-producing bacteria have not been determined. However, the growth of LCA-producing bacteria has been shown to be accelerated by vitamins such as vitamin $B_{12} \cdot{ }^{52)}$ Because regular mouse chow contains a larger amount of vitamin $B_{12}$ than the purified feed (Table 3), the vitamins contained in the regular mouse chow may have contributed to the increase in the LCA-producing bacterium, Clostridium sordellii, which was observed in this study.

In summary, it has been shown that CYP3A expression level in the liver is not affected by the intake of a high-fat diet. Therefore, it is possible that high-fat diet causes lifestyle that affects the pharmacokinetics of CYP3A substrates. $\left.{ }^{9}, 10\right)$ However, the possibility that the continuous intake of a highfat diet by itself could change the expression level of CYP3A and affect the pharmacokinetics of a CYP3A substrate is considered to be low. In addition, the enteric environment was altered when the animals were fed different diets, which triggered changes in the expression level and activity of CYP3A in the liver. The results of our study suggest that it is also necessary to carefully consider the type of feed used in the animal experiments.

\section{REFERENCES}

1) Thummel KE, Wilkinson GR. In vitro and in vivo drug interactions 
involving human CYP3A. Annu. Rev. Pharmacol. Toxicol., 38, 389-430 (1998).

2) Olinga P, Elferink MG, Draaisma AL, Merema MT, Castell JV, Pérez G, Groothuis GM. Coordinated induction of drug transporters and phase I and II metabolism in human liver slices. Eur. J. Pharm. Sci., 33, 380-389 (2008).

3) Masuyama H, Hiramatsu Y, Kunitomi M, Kudo T, MacDonald PN. Endocrine disrupting chemicals, phthalic acid and nonylphenol, activate Pregnane $\mathrm{X}$ receptor-mediated transcription. Mol. Endocrinol., 14, 421-428 (2000).

4) Toda T, Ohi K, Kudo T, Yoshida T, Ikarashi N, Ito K, Sugiyama K. Antibiotics suppress Cyp3a in the mouse liver by reducing lithocholic acid-producing intestinal flora. Yakugaku Zasshi, 129, 601-608 (2009).

5) Toda T, Ohi K, Kudo T, Yoshida T, Ikarashi N, Ito K, Sugiyama K. Ciprofloxacin suppresses Cyp3a in mouse liver by reducing lithocholic acid-producing intestinal flora. Drug Metab. Pharmacokinet., 24, 201-208 (2009).

6) Toda T, Saito N, Ikarashi N, Ito K, Yamamoto M, Ishige A, Watanabe K, Sugiyama K. Intestinal flora induces the expression of Cyp3a in the mouse liver. Xenobiotica, 39, 323-334 (2009).

7) Audet-Walsh E, Auclair-Vincent S, Anderson A. Glucocorticoids and phenobarbital induce murine CYP2B genes by independent mechanisms. Expert Opin. Drug Metab. Toxicol., 5, 1501-1511 (2009).

8) Thangavel C, Boopathi E, Shapiro BH. Intrinsic sexually dimorphic expression of the principal human CYP3A4 correlated with suboptimal activation of $\mathrm{GH} /$ glucocorticoid-dependent transcriptional pathways in men. Endocrinology, 152, 4813-4824 (2011)

9) Kudo T, Shimada T, Toda T, Igeta S, Suzuki W, Ikarashi N, Ochiai W, Ito K, Aburada M, Sugiyama K. Altered expression of CYP in TSOD mice: a model of type 2 diabetes and obesity. Xenobiotica, 39, 889-902 (2009).

10) Kudo T, Toda T, Ushiki T, Ohi K, Ikarashi N, Ochiai W, Sugiyama $\mathrm{K}$. Differences in the pharmacokinetics of Cyp3a substrates in TSOD and streptozotocin-induced diabetic mice. Xenobiotica, 40, 282-290 (2010).

11) Brunner LJ, Bai S. Effect of dietary oil intake on hepatic cytochrome P450 activity in the rat. J. Pharm. Sci., 89, 1022-1027 (2000).

12) Finn RD, Henderson CJ, Scott CL, Wolf CR. Unsaturated fatty acid regulation of cytochrome $\mathrm{P} 450$ expression via a CAR-dependent pathway. Biochem. J., 417, 43-54 (2009).

13) Landes N, Pfluger P, Kluth D, Birringer M, Rühl R, Böl GF, Glatt $\mathrm{H}$, Brigelius-Flohé R. Vitamin E activates gene expression via the pregnane X receptor. Biochem. Pharmacol., 65, 269-273 (2003).

14) Wang K, Chen S, Xie W, Wan YJ. Retinoids induce cytochrome P450 3A4 through RXR/VDR-mediated pathway. Biochem. Pharmacol., 75, 2204-2213 (2008).

15) Misra A, Singhal N, Khurana L. Obesity, the metabolic syndrome, and type 2 diabetes in developing countries: role of dietary fats and oils. J. Am. Coll. Nutr., 29 (Suppl.), 289S-301S (2010).

16) Do GM, Oh HY, Kwon EY, Cho YY, Shin SK, Park HJ, Jeon SM, Kim E, Hur CG, Park TS, Sung MK, McGregor RA, Choi MS. Long-term adaptation of global transcription and metabolism in the liver of high-fat diet-fed C57BL/6J mice. Mol. Nutr. Food Res., 55 (Suppl. 2), S173-S185 (2011).

17) Nishikawa S, Sugimoto J, Okada M, Sakairi T, Takagi S. Gene expression in livers of BALB/C and $\mathrm{C} 57 \mathrm{BL} / 6 \mathrm{~J}$ mice fed a high-fat diet. Toxicol. Pathol., 40, 71-82 (2012).

18) Koide CL, Collier AC, Berry MJ, Panee J. The effect of bamboo extract on hepatic biotransforming enzymes-Findings from an obese-diabetic mouse model. J. Ethnopharmacol., 133, 37-45 (2011).

19) Yao HT, Lii CK, Chou RH, Lin JH, Yang HT, Chiang MT. Effect of chitosan on hepatic drug-metabolizing enzymes and oxidative stress in rats fed low- and high-fat diets. J. Agric. Food Chem., 58, 5187-5193 (2010).

20) Yoshinari K, Takagi S, Yoshimasa T, Sugatani J, Miwa M. Hepatic CYP3A expression is attenuated in obese mice fed a high-fat diet. Pharm. Res., 23, 1188-1200 (2006).

21) Lowry OH, Rosebrough NJ, Farr AL, Randall RJ. Protein measurement with the Folin phenol reagent. J. Biol. Chem., 193, 265-275 (1951).

22) Laemmli UK. Cleavage of structural proteins during the assembly of the head of bacteriophage T4. Nature, 227, 680-685 (1970).

23) Perloff MD, von Moltke LL, Court MH, Kotegawa T, Shader RI, Greenblatt DJ. Midazolam and triazolam biotransformation in mouse and human liver microsomes: relative contribution of CYP3A and CYP2C isoforms. J. Pharmacol. Exp. Ther., 292, 618-628 (2000).

24) Yamaoka $K$, Tanigawara $Y$, Nakagawa T, Uno T. A pharmacokinetic analysis program (multi) for microcomputer. J. Pharmacobiodyn., $\mathbf{4}$, 879-885 (1981).

25) Nakashima K, Yamamoto K, Al-Dirbashi OY, Nakashima MN. Disposition of triazolam in the rat by brain microdialysis and semimicro column high-performance liquid chromatography with UV absorbance detection. Biomed. Chromatogr., 16, 219-223 (2002).

26) Ikarashi N, Kagami M, Kobayashi Y, Ishii M, Toda T, Ochiai W, Sugiyama K. Changes in the pharmacokinetics of digoxin in polyuria in streptozotocin-induced diabetic mice and lithium carbonatetreated mice. Xenobiotica, 41, 486-493 (2011).

27) Eyssen HJ, Parmentier GG, Mertens JA. Sulfate bile acids in germfree and conventional mice. Eur. J. Biochem., 66, 507-514 (1976).

28) Yamaguchi M, Matsunaga R, Fukuda K, Nakamura M, Ohkura Y. Highly sensitive determination of free polyunsaturated, long-chain fatty acids in human serum by high-performance liquid chromatography with fluorescence detection. Anal. Biochem., 155, 256-261 (1986).

29) Yamaguchi M, Matsunaga R, Hara S, Nakamura M, Ohkura Y. Highly sensitive determination of free fatty acids in human serum by high-performance liquid chromatography with fluorescence detection. J. Chromatogr. A, 375, 27-35 (1986).

30) Kim RB, Wandel C, Leake B, Cvetkovic M, Fromm MF, Dempsey PJ, Roden MM, Belas F, Chaudhary AK, Roden DM, Wood AJ, Wilkinson GR. Interrelationship between substrates and inhibitors of human CYP3A and P-glycoprotein. Pharm. Res., 16, 408-414 (1999).

31) Wang E, Lew K, Barecki M, Casciano CN, Clement RP, Johnson WW. Quantitative distinctions of active site molecular recognition by P-glycoprotein and cytochrome P450 3A4. Chem. Res. Toxicol., 14, 1596-1603 (2001).

32) Perloff MD, von Moltke LL, Cotreau MM, Greenblatt DJ. Unchanged cytochrome P450 3A (CYP3A) expression and metabolism of midazolam, triazolam, and dexamethasone in $\operatorname{mdr}(-/-)$ mouse liver microsomes. Biochem. Pharmacol., 57, 1227-1232 (1999).

33) Schrag ML, Wienkers LC. Triazolam substrate inhibition: evidence of competition for heme-bound reactive oxygen within the CYP3A4 active site. Drug Metab. Dispos., 29, 70-75 (2001).

34) Sidhu S, Malhotra S, Garg SK. Influence of high fat diet (butter) on pharmacokinetics of phenytoin and carbamazepine. Methods Find. Exp. Clin. Pharmacol., 26, 634-638 (2004).

35) Tan KK, Trull AK, Uttridge JA, Metcalfe S, Heyes CS, Facey S, Evans DB. Effect of dietary fat on the pharmacokinetics and pharmacodynamics of cyclosporine in kidney transplant recipients. Clin. Pharmacol. Ther., 57, 425-433 (1995).

36) Kang HJ, Song IS, Lee SS, Yoo MA, Shin JG. Effects of dietary salt on the expression of drug transporters, cytochrome P4503a, and nuclear receptors in rats. Xenobiotica, 38, 147-155 (2008).

37) Peters LP, Teel RW. Effects of high sucrose diet on body and liver weight and hepatic enzyme content and activity in the rat. In Vivo, 17, 61-65 (2003). 
38) van Waterschoot RA, Rooswinkel RW, Wagenaar E, van der Kruijssen $\mathrm{CM}$, van Herwaarden AE, Schinkel AH. Intestinal cytochrome P450 3A plays an important role in the regulation of detoxifying systems in the liver. FASEB J., 23, 224-231 (2009).

39) Staudinger JL, Goodwin B, Jones SA, Hawkins-Brown D, MacKenzie KI, LaTour A, Liu Y, Klaassen CD, Brown KK, Reinhard J, Willson TM, Koller BH, Kliewer SA. The nuclear receptor PXR is a lithocholic acid sensor that protects against liver toxicity. Proc. Natl. Acad. Sci. U.S.A., 98, 3369-3374 (2001).

40) Xie W, Radominska-Pandya A, Shi Y, Simon CM, Nelson MC, Ong ES, Waxman DJ, Evans RM. An essential role for nuclear receptors SXR/PXR in detoxification of cholestatic bile acids. Proc. Natl. Acad. Sci. U.S.A., 98, 3375-3380 (2001).

41) Parks DJ, Blanchard SG, Bledsoe RK, Chandra G, Consler TG, Kliewer SA, Stimmel JB, Willson TM, Zavacki AM, Moore DD, Lehmann JM. Bile acids: natural ligands for an orphan nuclear receptor. Science, 284, 1365-1368 (1999).

42) Yu J, Lo JL, Huang L, Zhao A, Metzger E, Adams A, Meinke PT, Wright SD, Cui J. Lithocholic acid decreases expression of bile salt export pump through farnesoid $\mathrm{X}$ receptor antagonist activity. $J$. Biol. Chem., 277, 31441-31447 (2002).

43) Han S, Li T, Ellis E, Strom S, Chiang JY. A novel bile acidactivated vitamin D receptor signaling in human hepatocytes. Mol. Endocrinol., 24, 1151-1164 (2010).
44) Matsubara T, Yoshinari K, Aoyama K, Sugawara M, Sekiya Y, Nagata K, Yamazoe Y. Role of vitamin D receptor in the lithocholic acid-mediated CYP3A induction in vitro and in vivo. Drug Metab. Dispos., 36, 2058-2063 (2008).

45) Ridlon JM, Kang DJ, Hylemon PB. Bile salt biotransformations by human intestinal bacteria. J. Lipid Res., 47, 241-259 (2006).

46) Gibson GR. Dietary modulation of the human gut microflora using prebiotics. Br. J. Nutr., 80, S209-S212 (1998).

47) Goldin B, Gorbach SL. Alterations in fecal microflora enzymes related to diet, age, lactobacillus supplements, and dimethylhydrazine. Cancer, 40 (Suppl.), 2421-2426 (1977).

48) Hawrelak JA, Myers SP. The causes of intestinal dysbiosis: a review. Altern. Med. Rev., 9, 180-197 (2004).

49) Villalon L, Tuchweber B, Yousef IM. Effect of a low protein diet on bile flow and composition in rats. J. Nutr., 117, 678-683 (1987).

50) Wu J, Peng SS. Comparison of hypolipidemic effect of refined konjac meal with several common dietary fibers and their mechanisms of action. Biomed. Environ. Sci., 10, 27-37 (1997).

51) Khan AA, Chow EC, Porte RJ, Pang KS, Groothuis GM. The role of lithocholic acid in the regulation of bile acid detoxication, synthesis, and transport proteins in rat and human intestine and liver slices. Toxicol. In Vitro, 25, 80-90 (2011).

52) Varel VH, Bryant MP. Nutritional features of Bacteroides fragilis subsp. fragilis. Appl. Microbiol., 28, 251-257 (1974). 